\title{
PEKERJA ANAK DI SEKTOR INFORMAL PENCUCIAN MOBIL TENGGARONG
}

\author{
Jumaidi Nur \\ Universitas Kutai Kartanegara \\ Jl. Gunung Kombeng 27 Tenggarong
}

\begin{abstract}
Children labors in the Car Wash Units informal sector is particularly obtained in Tenggarong, the capital of Kutai Kartanegara county. This condition is beyond an expected condition that Free Children Labor Zone in Kutai Kartanegara is executed in Kutai Kartanegara. This paper reports an identification on Children Labors in Car Wash Units in Tenggarong, providing other facts that a struggle is remaining necessary to make the program successful.
\end{abstract}

Key-words: children labors, informal sector, Kutai Kartanegara.

PEMERINTAH Kabupaten Kutai Kartanegara telah mencanangkan Program Zona Bebas Pekerja Anak (ZBPA) pada Tahun 2004 bahkan telah ditetapkan melalui Peraturan Daerah Kabupaten Kutai Kartanegara No. 9 Tahun 2004 dengan target pencapaian pada tahun 2007. Program ini merupakan program dunia yang diluncurkan oleh Perserikatan Bangsa-Bangsa melalui anak organisasinya Internatinal Labour Organisation (ILO).

Kabupaten Kutai Kartanegara adalah daerah yang pertama di Indonesia yang berani menerapkan program ini. Sekilas, program ZBPA tersebut nampak merupakan gebrakan yang luar biasa dan jika ditinjau dari aspek tujuan sangat positif dan mulia. Akan tetapi jika dikaji dan tinjau dari aspek perencanaan dan kesiapan dalam pelaksanaan di lapangan menurut penulis cenderung tidak akan mampu diimplemantasikan.

Masalah pendidikan dan masalah pekerja anak bukanlah sesederhana yang digambarkan karena menyangkut banyak aspek kehidupan masyarakat dan berbagai permasalahan yang muncul di tengah masyarakat. Selain itu tersedianya data dan informasi yang akurat belum sepadan dengan tujuan program ini. Sejauh ini, program ZBPA di Kabupetn Kutai kurang didukung oleh data dan informasi yang memadai untuk bahan perumusan dan pengambilan kebijakan, tetapi lebih cenderung mengarah kepada kehendak politik yang bersifat prestise dan kepentingan politik sesaat.

Ketika program itu diluncurkan pada tataran implementasi sudah mengalami kendala. Ditinjau dari sisi Peraturan Daerah, hasil workshop pemerintah Kabupaten Kutai Kartanegara dengan ILO dan Departemen Tenaga Kerja salah satu yang direkomendasikan oleh workshop tersebut ialah merevisi Peraturan Daerah karena tidak sesuai dengan ketentuan PBB melalui ILO maupun berdasarkan Ketentuan Ketenagakerjaan di Negara Indonesia.

Kita ketahui berdasarkan data pada Dinas Sosial Propinsi Kalimantan Timur, Kabupaten Kutai Kartanegara yang terkenal dengan kekayaannya merupakan daerah yang memiliki keluarga miskin yang terbesar yaitu 32.962 KK (Kaltim Post 17 Des 
2004). Menurut National Human Developmant Report 2004 (NHDR) pendapatan perkapita penduduk Kukar dalam satu bulan berada pada urutan ketujuh di Kaltim yaitu sebesar Rp 125,796. Selain itu, tingkat putus sekolah rata-rata di Kabupaten Kutai Kartanegara berada dalam urutan ketiga dan kelima. Berdasarkan usia, keadaan putus sekolah berturut-turut ialah usia 7-15 tahun 2,1\%, usia 16-18 tahun 18,7\%, dan usia 1924 tahun 16,7\%. Rata-rata pemerataan pendidikan juga rendah, berada dalam urutan ke7 di antara 13 daerah tingkat II se-Kaltim. Usia pemerataan pendidikan terendah ialah penduduk usia 7-15 tahun yaitu sebesar 97,5\%.

Banyak kasus terjadi anak-anak justru tidak betah tinggal di rumah bersama orang tua, tetapi justru tinggal di jalan-jalan, cenderung berkumpul dengan teman sebayanya dan mangkal di tempat-tempat umum lainnya, seperti di terminal, halte bus, perempat dan simpang lampu merah, serta tempat-tempat sejenis. Berbagai kegiatan mereka lakukan, mulai dari mengamen, sekedar nongkrong, hingga judi dan minum-minuman keras. Hal ini tentu saja sangat memprihatinkan dan amat meresahkan orang tua dan keluarga, meski sebenarnya semua itu bukanlah pilihan orang tuannya. Sudah tentu kegiatan dan dunia yang diciptakan oleh anak-anak tersebut adalah atas naluri dan cara berpikir mereka sendiri.

Tidak jarang berbagai kondisi memprihatinkan yang terjadi pada anak-anak tersebut, justru disebabkan oleh keadaan dan kondisi yang sengaja diciptakan atau sengaja dikondisikan. Anak-anak dipaksa untuk berbuat dan bersikap, di luar kemampuan dan kemauannya sendiri, seperti; mengemis, mengamen, menjual koran, serta melakukan pekerjaan-pekerjaan sejenis yang tidak sesuai dengan jiwa dan karakter anak-anak. Pada kondisi yang demikian, anak-anak tak ubahnya seperti obyek perbudakan dan sering diperlakukan amat tidak mausiawi. Padahal sejatinya anak-anak ini masih akan tumbuh dan berkembang menjadi orang dewasa yang menggantikan generasi selanjutnya, dan sesungguhnyalah dunia anak adalah dunia bermain, penuh kasih sayang dan perhatian, bukan dunia kerja.

Kabupaten Kutai Kartanegara, sebagai salah satu Kabupaten yang berani mencetuskan gagasan untuk membebaskan daerahnya dari pekerja anak, dengan dituangkan dalam bentuk Peraturan Daerah Nomor 9 Tahun 2004 tentang Zona Bebas Pekerja Anak sebagai realisasi dari Undang-undang Nomor 23 tahun 2002, telah menetapkan Kabupaten Kutai Kartanegara sebagai Zona Bebas Pekerja Anak pada Tahun 2007 nanti. Berbagai langkah telah dilakukan dan berbagai program telah diupayakan, namun tidak berarti bahwa permasalahan pekerja anak telah usai semuanya. Karena sesungguhnya praktek-praktek pekerja anak masih dapat kita lihat di mana saja.

Dalam melaksanakan Peraturan Daerah tersebut, diperlukan peran aktif semua fihak, baik Pemerintah Daerah, Lembaga Swadaya Masyarakat (LSM), Serikat Pekerja/Serikat Buruh, Organisasi Pengusaha dan Masyarakat pada umumnya. Pelanggaran terhadap Peraturan Daerah tersebut akan dikenakan sanksi secara hukum, baik sanksi pidana kurungan paling lama 6 (enam) bulan atau membayar denda paling banyak Rp.5.000.000,00 (lima juta rupiah) seperti ketentuan Peraturan Daerah Nomor 9 Tahun 2004 tentang Zona Bebas Pekerja Anak Bab VI Pasal 10.

\section{METODE}


Sedangkan populasi dalam penelitian ini adalah pekerja anak yang terdapat pada 2 (dua) tempat pencucian mobil dan motor yaitu pencucian mobil dan motor Langganan Etam dan pencucian mobil dan motor Ibu Sri di Kelurahan Baru Kecamatan Tenggarong. Sebanyak 10 (sepuluh) orang (pekerja anak dibawah 18 tahun) sebagaimana table dibawah ini:

Tabel 1. Data Pekerja Anak pada Pencucian Mobil dan Motor Langganan Etam dan Pencucian Mobil dan Motor Ibu Sri.

\begin{tabular}{|l|l|c|l|}
\hline No & \multicolumn{1}{|c|}{ Nama } & Umur & Keterangan \\
\hline 1. & Ralunadi Budiawan & 14 tahun & Pencucian Langganan Etam \\
\hline 2. & Amrulla & 17 tahun & Pencucian Ibu Sri \\
\hline 3. & M.Mirza & 16 tahun & Pencucian Ibu Sri \\
\hline 4. & Ase Hida at & 17 tahun & Pencucian Ibu Sri \\
\hline 5. & Rozy Andika & 14 tahun & Pencucian Ibu Sri \\
\hline b. & Ardian ah & 18 tahun & Pencucian Lan an \\
\hline 7. & Ari Setiawan & 14 tahun & Pencucian Ibu Sri \\
\hline 8 & Budi Santoso & 16 tahun & Pencucian Ibu Sri \\
\hline 9. & Wahyu I. & 18 tahun & Pencucian Langganan \\
\hline 10. & Santo & 18 tahun & Pencucian Langganan \\
\hline
\end{tabular}

Mengingat jumlah populasi Pekerja Anak pada 2 (dua) tempat pencucian tersebut relatif kecil dan terjangkauan oleh peneliti, maka sampel diambil sebanyak 10 orang anak yang usianya sesuai dengan batasan umur yang ditetapkan pada Konvensi Internasional Labour Organization (ILO) dan UndangUndang Nomor 23 Tahun 2002 tentang Perlindungan Anak pada Bab 1 pasal 1 ayat 1. Data diperoleh melalui wawancara dan angket.

\section{HASIL DAN BAHASAN}

Sebagian besar responden pekerja anak itu adalah laki-laki. Di pencucian mobil dan motor 'Ibu Sri' jumlahnya mencapai 6 (enam) orang anak, sedangkan di 'Langganan Etam' juga sebanyak 4 (empat) orang anak. Pekerja anak di pencucian mobil dan motor 'Ibu Sri' mulai bekerja pada usaha tersebut, mulai pada umur yang relatif lebih tua dibanding dengan pekerja anak pada pencucian mobil dan motor 'Langganan Etam'. Pekerja anak di pencucian mobil dan motor 'Ibu Sri' mulai bekerja sejak mereka menginjak usia Sekolah Menengah Pertama (SMP), sementara di pencucian mobil dan motor 'Langganan Etam', mereka mulai bekerja ketika menginjak bangku Sekolah Dasar (SD).

Secara keseluruhan pekerja anak di dua lokasi tersebut masih bersekolah, namun pada pencucian mobil dan motor 'Langganan Etam' terdapat 1 anak dari 4 orang pekerja anak tersebut sudah tidak bersekolah lagi. Sebagian besar pekerja anak di dua lokasi pencucian tersebut yang diwawancarai tidak ingin meneruskan sekolah setelah lulus nanti karena kurangnya minat dan mereka pikir tidak cukup biaya untuk melanjutkan pendidikan mereka.

Sebagian besar mengatakan tidak mampu dan tidak ingin sekolah lagi, dan pmereka berfikir sekolah cukup sampai jenjang SMP atau SMA saja. Alasan lainya 
adalah kepuasaan yang didapat dari berkerja dan mendapat uang menyebabkan mereka tidak tertarik sekolah lagi, Mereka mengikuti teman yang putus sekolah atau yang sudah lulus serta karena telah bekerja di bidang ini. Data selengkapnya tentang Pekerja Anak Sektor Informal yang diteliti dapat dilihat pada Tabel 1 dan Tabel 2.

Tabel 1. Data Pekerja Anak di Pencucian Mobil dan Motor Ibu Sri

\begin{tabular}{|l|l|l|l|}
\hline No & Nama & Umur & Penghasilan/Hari \\
\hline 1 & Rozi & 14 & 10.000 \\
\hline 2 & Andika & 16 & 10.000 \\
\hline 3 & Asep Hidayat & 17 & 6.000 \\
\hline 4 & M. Mirza & 14 & 7.000 \\
\hline 5 & Amrula & 16 & 7.000 \\
\hline 6 & Ari S. & 17 & 10.000 \\
\hline 7 & Budi & 14 & 6.000 \\
\hline
\end{tabular}

Tabe1 2. Data Pekerja Anak di Pencucian Mobil dan Motor`Langganan Etam'

\begin{tabular}{|l|l|l|l|l|l|l|l|}
\hline No & Nama & Alamat & Sekolah & $\begin{array}{l}\text { Alamat } \\
\text { Ortu }\end{array}$ & Umar & $\begin{array}{l}\text { Peker- } \\
\text { jaan } \\
\text { Ortu }\end{array}$ & $\begin{array}{l}\text { Hasil } \\
\text { /hari } \\
\text { R }\end{array}$ \\
\hline 1 & Wahyu I. & $\begin{array}{l}\text { AM. } \\
\text { Sangaji }\end{array}$ & $\begin{array}{l}\text { Putus } \\
\text { sekolah }\end{array}$ & $\begin{array}{l}\text { Tengga } \\
\text { rong }\end{array}$ & 18 th & Petani & $\begin{array}{l}10.000 \\
\text { s/d } \\
30.000\end{array}$ \\
\hline 2 & $\begin{array}{l}\text { Rahmadi } \\
\text { Budiawan }\end{array}$ & $\begin{array}{l}\text { AM. } \\
\text { Sangaji }\end{array}$ & SMP 2 & $\begin{array}{l}\text { Tengga } \\
\text { rong }\end{array}$ & 74 th & $\begin{array}{l}\text { Ibu } \\
\text { rumah } \\
\text { Tngga }\end{array}$ & $\begin{array}{l}10.000 \\
\text { s/d } \\
30.000\end{array}$ \\
\hline 3 & Santo & $\begin{array}{l}\text { AM. } \\
\text { Sangaji }\end{array}$ & SMK 1 & $\begin{array}{l}\text { Ma. } \\
\text { Ancalong }\end{array}$ & 18 th & Petani & $\begin{array}{l}10.000 \\
\text { s/d } \\
30.000\end{array}$ \\
\hline 4 & $\begin{array}{l}\text { Ardian } \\
\text { Syah }\end{array}$ & $\begin{array}{l}\text { AM. } \\
\text { Sangaji }\end{array}$ & $\begin{array}{l}\text { SMA } \\
\text { YPK }\end{array}$ & $\begin{array}{l}\text { Tengga } \\
\text { rong }\end{array}$ & 18 th & Petani & $\begin{array}{l}10.000 \\
\text { s/d }\end{array}$ \\
& & & & & & 30.000 \\
\hline
\end{tabular}

Ada perbedaan antara pekerja anak di pencucian mobil dan motor Ibu Sri' dan di pencucian mobil dan motor 'Langganan Etam', dalam ha1 hubungan mereka dengan pemilik pencucian. Di pencucian mobil dan motor 'Ibu Sri' dalam merekrut pekerja anak selain berdasarkan saling kenal juga atas dasar kebaikan hati si pemilik pencucian yang tulus ingin menolong anak-anak tersebut, sehingga wajar jika mereka punya hubungan yang akrab karma kesamaan diantara mereka. Sedangkan di pencucian mobil dan motor 'LanggananEtam' hubungan dengan pemilik pencucian selain saling kenal juga adanya hubungan keluarga. Keterlibatan pekerjaan anak di 
sektor ini biasanya terjadi ketika pemilik pencucian melakukan usaha sendiri di rumah dan anak-anak akhirnya ikut serta membantu usaha mereka. Mereka tetap bersekolah dan baru bekerja sepulang sekolah atau bagi mereka yang masuk siang hari maka bekerjanya di pagi hari.

Tabe13. Ragam Hubungan Pekerja dengan Pemilik Pencucian

\begin{tabular}{|l|c|c|}
\hline \multicolumn{1}{|c|}{ Responden } & Ibu Sri & $\begin{array}{c}\text { Langganan } \\
\text { Etam }\end{array}$ \\
\hline Anak pemilik & 0 & 1 \\
Saudara pemilik & 1 & 2 \\
Tetangga / anak warga sekitar & 3 & 1 \\
Anak daerah lain & 2 & 0 \\
\hline
\end{tabular}

\section{Faktor-Faktor Yang Melatarbelakangi Anak Untuk Bekerja}

Hasil wawancara dan diskusi terfokus menunjukkan beberapa hal yang menyebabkan anak bekerja. Faktor-faktor itu antara lain:

\section{Keinginan memiliki uang/penghasilan sendiri}

Karena mereka ingin tetap bersekolah dan membeli barang-barang seperti umumnya anak-anak seusia mereka maka apabila harus bekerja untuk mendapatkan penghasilan sendiri.

\section{Membantu orang tua}

Sebagaian pekerja anak tersebut adalah keluarga besar dengan jumlah saudara yang banyak sehingga denagn mereka bekerja mereka bisa sedikit meringankan beban orang tua.

\section{Kemiskinan}

Orang tua pekerja anak tersebut sebagian besar adalah pekerja-pekerja kasar, buruh rendahan. Dengan penghasilann yang relative rendah dan tidak menentu. Mereka adalah keluarga miskin yang terpaksa merelakan anaknya untuk bekerja.

\section{Ikut teman}

Hamper semua pekerja anak tersebut tersebut pada awalnya bekerja karena terpengaruh oleh teman yang sudah bekerja di pencucian.

5. Pekerja tidak punya keahlian lain.

Semua pekerja anak di pencucian tersebut tidak mempunyai keahlian lain yang bisa membuat mereka diterima pada tempat (pekerjaan) yang lebih baik lagi.

Seraca umum tidak ada perbedaan yang mencolok antara pekerja anak Pencucian mobil dan motor di Pencucian "Langganan Etam" dan Pencucian "Ibu Sri" mayoritas Kutai Islam. Terdapat sedikit perbedaan umur dan karekteristik pekerja anak di kedua tempat pencucian tersebut. Informasi berikut merupakan hasil wawancara dengan delapan (8) anak dari kedua tempat pencucian tersebut dan 13 anak yang mengisi angket. 
Semua responden adalah anak laki-laki. Sebagian besar pekerja anak di pencucian Langganan Etam bekerja sejak mereka masih Sekolah Dasar (SD), bahkan ada yang dari kelas 3 SD sudah bekerja. Sedangkan di pencucian Ibu Sri anak-anak mulai bekerja setelah duduk di bangku SMP.

Tabel 4. Persentase Faktor-faktor Yang Melatarbelakangi Anak-anak Untuk Bekerja

\begin{tabular}{llcccc}
\cline { 2 - 5 } No & $\begin{array}{c}\text { Faktor-Faktor } \\
\text { Penyebab }\end{array}$ & $\begin{array}{c}\text { "Dewi Sri" } \\
\text { (Jumlah) }\end{array}$ & $\begin{array}{c}\text { Persentase } \\
(\%)\end{array}$ & $\begin{array}{c}\text { "Langganan } \\
\text { Etam" } \\
\text { Jumlah }\end{array}$ & $\begin{array}{c}\text { Persentase } \\
(\%)\end{array}$ \\
\hline 1 & $\begin{array}{l}\text { Ingin Mencari } \\
\text { Uang }\end{array}$ & 6 & $100 \%$ & 4 & $100 \%$ \\
\hline 2 & Membantu Ortu & 2 & $57,14 \%$ & 3 & $83,33 \%$ \\
\hline 3 & Kemiskinan & 2 & $57,14^{\circ \circ}$ & 2 & $66,67^{\circ} 0^{\circ}$ \\
\hline 4 & Ikut Teman & 6 & $100 \%$ & 4 & $100 \%$ \\
\hline 5 & Nganggur & 6 & $100 \%$ & 4 & $100 \%$ \\
\hline
\end{tabular}

\section{BAHASAN}

Secara umum pekerja anak di kedua tempat pencucian tersebut hampir semuanya masih sekolah dan satu anak yang putus sekolah. Mereka sekolah di SMP dan SMA. Dari segi penghasilan, mereka mengatakan bahwa penghasilan yang mereka peroleh dari mencuci mobil dan motor masih belum mencukupi untuk biaya hidup sehari-hari serta biaya sekolah. Mereka bekerja dari sekitar pukul 05.30 pagi hingga siang menjelang berangkat ke sekolah. Jika sekolahnya masuk pagi mereka bekerja setelah pulang sekolah hingga sore hari bahkan sampai pukul 21.00 malam.

Pekerja anak yang bekerja di pencucian mobil dan motor hampir semua bekerja atas kemauan mereka sendiri, walaupun ada juga sebagian yang bekerja karena diajak teman. Sebelum ke sekolah atau setelah pulang sekolah mereka mempunyai waktu luang dan juga dikarenakan rumah tempat tinggal mereka dekat dengan lokasi tempat pencucian. Bahkan ada yang tinggal dengan majikan pencucian. Karena pekerja anak tersebut sebagian besar tidak tinggal dengan orang tua mereka, orang tua mereka tinggal di luar Kecamatan Tenggarong bahkan ada yang tinggal di luar Kaltim.

Pekerja anak tersebut mendapat gaji harian, umumnya mereka mendapatkan gaji sore atau malam hari setelah pencucian tutup. Dan pendapatan mereka dihitung berdasarkan berapa mobil dan motor yang telah mereka cuci pada hari itu. Malam hari mereka punya waktu luang buat belajar atau jalan jalan bersama temantemannya. 
Pada umumnya pekerja anak di kedua tempat pencucian tersebut memilih akan tetap terus bekerja dengan beragam alasan, mulai dari ingin membantu orang tua, sulitnya mendapat pekerjaan baru yang lain dengan keterbatasan keahlian yang mereka miliki sampai merasa senang bekerja. Karena walaupun bekerja mereka masih bisa bersekolah. Meski secara sikap anak bekerja untuk mendapatkan pengakuan dan secara emosi karena mendapatkan imbalan, namun sesungguhnya hal ini bertentangan dengan nilai-nilai kodrati seorang anak dan melanggar hak hak anak secara menyeluruh. Jadi walaupun menurut anak-anak pekerjaan yang dilakukannya sangat menyenangkan, namun sesungguhnya itu merupakan suatu permasalahan yang perlu mendapat perhatian serius.

Berdasarkan Buku Paket Informasi ZBPA yang dikeluarkan dalam rangka Kampanye Penghapusan Pekerja Anak di Kabupaten Kutai Kartanegara (2004: 9) pekerja anak menjadi masalah karena berbagai alas an.

- Pekerja anak mengingkari hak dasar anak, seperti hak untuk bersekolah, hak untuk bermain, hak untuk tidak diperlakukan secara tidak baik.

- Tubuh anak masih berkembang clan belum terbentuk secara penuh. Anakanak mengalami pertumbuhan kesehatan fisik yang buruk, karena pekerjaan yang mereka lakukan dapat mengganggu kesehatan, menimbulkan penyakit atau kelelahan. Misalnya karena mengangkat beban berat atau posisi tubuh ketika bekerja tidak normal, seperti berjongkok.

- Anak-anak lebih mudah tercemar bahaya dari bahan kimia dan radiasi.

- Anak-anak lebih mudah terserang penyakit.

- Anak-anak seringkali bekerja dalam lingkungan berbahaya dan terasing. Mereka seringkali mengalami perlakuan buruk, kekerasan, disepelekan oleh majikan Anak-anak ini akan sulit untuk membentuk rasa kasih dan rasa memiliki terhadap orang lain. Mereka bermasalah dalam pergaulan dan bekerja dengan orang lain serta dalam mencari identitas diri.

- Anak-anak didorong ke dalam dunia dewasa sebelum waktunya. Mereka tidak memiliki waktu untuk melakukan aktivitas yang berguna untuk tumbuh kembang mereka seperti bermain, bersekolah dan bergaul dengan teman sebaya. Mereka tidak memiliki pendidikan dasar yang diperlukan untuk menjalani kehidupan.

Dilihat dari latar belakang keluarga, sebagian besar orang tua responden berpendidikan rendah dan bekerja hanya sebagai buruh rendahan seperti petani kecil, tukang becak, orang tuanya hanya ibu rumah tangga biasa dan lain-lain. Menurut mereka hampir semua orang tua mereka setuju anak mereka bekerja. Mereka menganggap itu lebih baik daripada hanya menganggur di rumah atau keluyuran. Pendapatan mereka hal itu dapat meringankan beban keluarga. Pemilik pencucian menolak dianggap memanfaatkan tenaga anak-anak. Mereka menganggap bahwa mereka menyediakan "kesempatan kerja" bagi anak-anak. Setelah lulus SD, anak dianggap sebagai remaja belasan tahun yang akan tumbuh dewasa, sehingga perlu belajar bekerja paruh waktu agar bisa belajar mencari uang sendiri. 
Dalam memahami konsep lingkungan perkembangan anak inilah, pekerja anak yang bekerja pada sektor informal dianggap bahwa lingkungan tempat mereka bekerja sesungguhnya tidak layak bagi perkembangan diri mereka. Lingkungan yang sesungguhnya adalah dipilih yang dapat mempengaruhinya baik secara fisik maupun sosial, dengan demikian perkembangan fisik, psikologis, sosial budaya mereka dapat berkembang secara wajar.

Pekerja anak yang bekerja disektor informal merupakan salah satu kategori pekerjaan yang terlarang bagi anak yaitu termasuk kategori pekerjaan berbahaya bagi anak. Kajian singkat ILO-IPEC tentang anak-anak yang terlibat pada kegiatan industri sektor informal menunjukan bahwa lingkungan tempat kerja sangat mengancam keselamatan, kesehatan dan kesejahteraan mereka. Mereka umumnya rentan terhadap bahaya unsur biologis, bahan kimia, psikologis dan fisik mereka.

\section{SIMPULAN}

Berdasarkan temuan di atas, dapat disimpulkan bahwa factor-faktor yang melatarbelakangi anak senang bekerja di pencucian mobil dan motor antara lain keinginan memiliki uang/penghasilan sendiri, membantu orang tua, kemiskinan, ikutikutan teman, dan tidak ada kegiatan lain (nganggur). Sebagian besar dari pekerja anak di pencucian mobil dan motor tersebut berasal dari keluarga miskin, sehingga sepertinya akibat kemiskinan mereka terpaksa bekerja dan ikut bertanggung jawab terhadap keluarganya dengan bekerja untuk membantu ekonomi keluarga. Anak-anak juga terdorong untuk meniru perilaku orang lain, seperti membeli kelengkapan dan barangbarang sebagaimana umumnya anak-anak seusianya, misalkan gaya hidup dan mode, serta tatacara bergaul menyebabkan anak-anak yang bekerja di sektor informal pencucian mobil dan motor tidak ingin berhenti bekerja hingga waktu tertentu.

Bagaimanapun juga hasilnya, secara ekonomis sebenarnya bekerja pada sektor informal bagi anak-anak adalah hal yang membahayakan. Baik dari segi fisik, biologis maupun dari segi psikologi sosial pada diri anak. Namun, kondisi lingkungan sosial, sikap orang tua, serta pandangan sebagian masyarakat bahwa anak-anak yang bekerja merupakan wujud bakti anak pada orang tua, banyak mendorong timbulnya pekerja anak pada sektor informal dengan mengabaikan dampak yang ditimbulkan.

\section{SARAN}

1. Sebagai bahan sosialisasi, agaknya keberadaan pekerja anak perlu mendapat perhatian serius agar masyarakat mulai memiliki perhatian terhadap masalah pekerja anak dan dampak yang ditimbulkannya.

2. Sebagai konsekuensi bahwa anak adalah amanah dan menyia-nyiakannya adalah dosa, maka setiap orang tua wajib melindungi anak-anaknya dari berbagai kegiatan eksploitasi dan berbagai pekerjaan yang tidak sesuai dengan perkembangan psikologi dan fisiknya, serta membahayakan keselamatan hidupnya. Keluarga juga berkewajiban membimbing atau membiasakan anggotanya untuk mempelajari dan mengamalkan ajaran agama yang dianutnya. 
3 Sebagai anggota masyarakat kita juga wajib mendukung kegiatan Program Zona Bebas Pekerja Anak di Kabupaten Kutai Kartanegara yang mulai dicetuskan sejak tahun 2004 lalu.

4. Dengan melihat gambaran di lapangan, bahwa masih ada pekerja anak yang bekerja dan itu membahayakan bagi diri mereka, maka diharapkan komintmen para pemimpin daerah khususnya yang menyangkut pendidikan dan kesejahteraan anak dapat betul-betul diwujudkan.

5. Alternatif terbaik untuk menghindari anak-anak menjadi pekerja sektor informal adalah dengan menyekolahkannya agar dapat berubah pola pikir, cara bergaul dan memberi kegiatan yang positif melalui berbagai kegiatan di sekolah guna mengisi waktu luangnya.

\section{DAFTAR PUSTAKA}

Depnakertrans. 2003. Undang-Undang Republik Indonesia Nomor 13 Tahun 2003 tentang Ketenagakerjaan. Jakarta: Depnakertran.

Depdagri. 2002. Undang-Undang Republik Indonesia Nomor 23 Tahun 2002 tentang Perlindungan Anak. Jakarta: Depdagri.

Kerlinger, Fred N. 1992. Asas-asas Penelitian Behaviororal. Edisi Ketiga Terj. Landung R Simatupang. Yogyakarta: Gadjah Mada University Press.

Moleong, Lexy J. 2000. Metodologi Penelitian Kualitatif. Bandung: Remaja Rosdakarya.

Nasution, S. 2000. Metodologi Penelitian Naturalistik Kualitatif. Bandung: Tarsito.

Plus A Partanto., \& M. Dahlan Al Banary. 2001. Kamus Ilmiah Populer. Surabaya: Arloka.

Poerwadarminto, W.J.S. 2002. Kamus Besar Bahasa Indonesia. Jakarta: Balai Pustaka.

Subana, M. \& Sudrajat. 2001. Dasar-dasar Penelitian Ilmiah. Bandung: Pustaka Setia.

Sudarsono, FX. 1995. Analisis Data Kualitatif. Yogyakarya: Lemlit UNY. Sugiyono. 2002. Statistik Untuk Penelitian. Bandung: CV.

Alfabeta.

Sudarmayanti \& Syarifudin Hidayat. 2002. Metodologi Penelitian. Bandung: Mandar Maju

UNICEF. 2000. Konvensi PBB tentang Perlindungan Pekerja Anak. Jakarta: PBB UNICHEF.

Usman, Husaini, \& Akbar, Purnomo Setiadi. 2004. Metodologi Penelitian Sosial. Jakarta: Bumi Aksara.

Yusuf, Syamsu, \& Dahlan, Djawad. 2004. Psikologi Perkembangan Anak dan Remaja. Bandung: Remaja Rosdakarya. 
CENDEKIA, Vol. 9, No. 2, Oktober 2015

p ISSN: 1978 2098; e ISSN: 2407 8557; Web: cendekia.pusatbahasa.or.id

Pusat Kajian Bahasa dan Budaya, Surakarta, Indonesia

Nur, Jumaidi. 2015. Pekerja Anak di Sektor Informal Pencucian Mobil Tenggarong. Cendekia, 9(2): 223 232. 